\title{
Feeding strategies for improving ruminant productivity in the post-COVID 19 pandemic era particularly for small holders
}

\author{
Dennis P. Poppi*1), Kusmartono Kusmartono ${ }^{2)}$, Kasmyati Kasmyati ${ }^{3)}$, Simon P. Quigley ${ }^{1)}$ and \\ Karen J. Harper ${ }^{1)}$ \\ 1) School of Agriculture and Food Science, University of Queensland, Australia \\ ${ }^{2)}$ Faculty of Animal Science, University of Brawijaya, Malang, Indonesia \\ ${ }^{3)}$ Assessment Institute for Agricultural Technology, Malang, Indonesia
}

Submitted: 09 February 2021, Accepted: 16 March 2021

\begin{abstract}
COVID-19 has highlighted the need for robust cattle supply chains using local feed resources. Higher Income Over Food Costs (IOFC) are usually achieved when live weight gains are high and the cost of the ingredients are low. There is a need to formulate rations with high metabolisable energy (ME) and crude protein (CP) to achieve the high live weight gain. Rations can be formulated locally by farmer co-operatives, entrepreneurs and local commercial enterprises to take advantage of cheaper prices for local ingredients. To do this, rations need to be altered quickly to take advantage of local fluctuations in prices and availability of ingredients. A recent ACIAR funded project has developed a least cost ration (ACIAR LCR) system to formulate rations to meet minimum $\mathrm{ME}$ and $\mathrm{CP}$ contents for beef cattle using locally available ingredients. The use of cassava and its various products in combination with protein sources, such as tree legumes and high protein by-products, have markedly improved IOFC.
\end{abstract}

Keywords: Cassava; Income over food costs; Least cost ration; Local feed resources

*Corresponding Author: d.poppi@uq.edu.au 


\section{INTRODUCTION}

The pandemic Covid-19 has highlighted the sensitivity of the local supply chains to both local and international restrictions on the movement of animals and people. This has resulted in a cessation or restriction in certain markets particularly those relying on international trade. The ruminant industry has been affected internationally with restrictions on movement of meat and live animals. Indonesia and similar countries with a reliance on local trading and wet markets have seen difficulties as well as opportunities and this impacts on smallholders more than other commercial enterprises as they have more reliance on local trading and fewer opportunities for alternative markets. The reduction in income for a large sector of the population makes it very difficult. This has highlighted the need to develop more resilient production systems that improve the income over feed costs for an enterprise and have more reliance on local supply chains. There is a need for farmers to be able to participate in the potential for livestock enterprises, in particular beef cattle, to increase income over the subsistence systems of production. Improving the throughput of cattle sales of a farmer would also help Indonesia reach selfsufficiency in beef but more importantly help the farmer to participate in the supply chain and profit of a better system of production.

\section{DISCUSSION}

\section{How might farmers increase their income from cattle?}

Current systems of production are low in terms of reproduction rate and live weight gain. Many surveys have shown that reproduction rate varies from $35-77 \%$ across Indonesia (Wirdahayati 1994) and that live weight gain under village systems are low varying from $0.3-0.5 \mathrm{~kg} / \mathrm{d}$ for Ongole bulls (Arygoyi et al 2005, Pamungkas et al 2012, Pryanti et al 2012). These show that under many current systems of production farmers feed cattle on cost of ingredients rather than some formulation for high metabolisable energy (ME) and crude protein (CP) content and this results in poor live weight gain and income over feed costs (Pryanti et al 2012). The best strategy is to increase live weight gain (not necessarily to genetic potential) at a low cost. It is very easy to increase live weight gain for a high cost. Some system of designing rations that can be changed as costs change is required if farmers are to have profitable strategies to increase live weight gain.

\section{Terminology to understand the strategies}

There are two aspects to profit from a beef fattening enterprise, market price of the animal and cost of feed, labour and infrastructure. The market price of an animal in the live trading market place can be monitored but market information and power lies in the hands of the traders rather than the farmers. Nevertheless value can be assigned to an animal although it is often not a simple IDR/kg live weight and can depend on the timing of sale for religious festivals or family needs. The cost of production depends primarily on the feed cost and the conversion of feed to live weight gain so it is important to focus on some key features relating to cost of production.

Feed conversion ratio (FCR) (kg feed/kg live weight gain) is very important and can be improved by choice of feed. Feed conversion efficiency is also expressed as the $\mathrm{kg}$ live weight gain $/ \mathrm{kg}$ feed. Both means of expression are applicable but terms such as high or low feed efficiency depend on the mode of expression. Here we use the FCR term $\mathrm{kg}$ feed $/ \mathrm{kg}$ live weight gain as that is more readily applied to assessing differences in rations in cost and production. Hence a low FCR is a better system of production. Feedlot rations result in a low FCR (eg 5-7 kg feed/kg live weight gain) compared to forage based rations especially those forages of low digestibility and ME (eg 13-25 kg forage/kg live weight gain). Thus rations which promote a high live weight gain have the more desirable FCR ie 
lower FCR than rations which promote a low live weight gain. Low live weight gain might result from using a ration with a low intake and ME content such as low quality rice straw or cut and carry grasses or by farmers not offering the animal as much feed as they can eat ie restricting the intake by not understanding that the animal can eat more. High live weight gain results from feeding a forage of high digestibility (ME content) or by using a formulated ration using various by-products to have a high ME ration. This is sometimes called a concentrate but here we prefer to use the term formulated ration as that implies that the ration is a mix of ingredients which could also include roughages. The FCR can be simply converted to a cost of gain by multiplying the FCR ( $\mathrm{kg}$ feed/ $/ \mathrm{kg}$ live weight gain) by the cost of the feed (IDR $/ \mathrm{kg}$ feed). This can then simply be compared to the expected return of the weight gain in the market place as in IDR/kg live weight. Profit or loss can be quickly assessed and compared between feeding strategies.

Whilst this approach is quick and simple it does not take into account throughput or turnover in an enterprise. For this reason Pryanti et al (2012) have used the parameter daily income over food cost (IOFC). It provides an estimate of the daily profit from a strategy which, for a smallholder, is probably more important when both short and long term decisions are being made as to how to approach fattening cattle for sale and the benefits from a fattening enterprise. The units are the same ie Income is derived from the sale price (estimated or real from the market place) and costs are based on the cost of feed $/ \mathrm{kg}$ which can include labour and infrastructure costs.

$$
\begin{aligned}
\mathrm{IOFC}= & \text { (daily live weight gain }(\mathrm{kg} / \mathrm{d}) \times \text { sale } \\
& \text { price }(\mathrm{IDR} / \mathrm{kg} \text { live weight }))-(\mathrm{kg} \\
& \text { feed required daily } \mathrm{x} \text { cost } / \mathrm{kg} \text { feed }) .
\end{aligned}
$$

Table 1. Cost (IDR/kg as fed) of common ingredients across 4 sites in Indonesia (at July August 2020)

\begin{tabular}{lcccc}
\hline Feed type & East Java & Yogyakarta & Central Sulawesi & Sumbawa \\
\hline Corn grain & 3800 & 5000 & 4000 & $3800-4200$ \\
Cassava powder (Gaplek) & 2500 & $4500-5500$ & 5500 & $2800-4000$ \\
Cassava fresh tubers & 1000 & na & na & na \\
Cassava fresh tubers cost of production & 400 & na & na & \\
by farmer & & & na & 2800 \\
Cassava bagasse (Onggok) & 1700 & 4000 & 2500 & 2500 \\
Rice bran & 2500 & $3500-4500$ & na & na \\
Wheat bran (pollard) & 3600 & $3300-3600$ & 2800 & 1800 \\
Palm kernel cake & 2100 & 2700 & 3500 & 4500 \\
Copra meal & 3100 & 4500 & na & 6500 \\
Soybean meal & 6600 & $5000-7000$ & 500 & 600 \\
Gliricidia & 1000 & 500 & 500 & 600 \\
Leucaena & na & na & 500 & 450 \\
Elephant grass & 350 & 700 & 200 & 200 \\
Rice straw & 250 & 200 & 350 & 200 \\
Corn stover & na & 200 & 3500 & 3500 \\
urea & 3200 or 6000 & 8000 (not & & \\
& (not subsidized) & subsidised) & & \\
\hline
\end{tabular}

na Not available: not grown in region or prices not available

The cost $/ \mathrm{kg}$ feed is obtained from market prices and whilst home grown feed (forage, tree legumes, crops and straw) is often given a zero value it is best to include a labour and infrastructure cost in the cost $/ \mathrm{kg}$ feed. For an individual farmer this is debatable and depends very much on personal circumstances eg 1 hour gathering tree legumes can be assigned a cost but for a particular farmer there may be no cost as the opportunity to use that extra 1 hour on another labour activity is non-existent. 
Economists debate this regularly but in developing a national or regional strategy it is important to account for labour but in individual advice to a farmer this may be discounted heavily depending on personal circumstances. Prices vary markedly across Indonesia (Table 1) and the Covid-19 pandemic has interrupted the supply chain across Indonesia and increased the variability. This is not an exhaustive list but it outlines the major feed ingredients available to farmers. Farmers use a mixture of feed types based largely on cost of the feed type rather than its potential to promote a high LWG (Ratnawati et al 2015, Pryanti et al 2012). Whilst the daily cost was low the daily LWG was also low as was the daily IOFC. Rations formulated for higher ME and CP content should promote a high LWG in line with accepted nutritional principles. Research can often indicate a ration composition which promotes high LWG and may or may not promote a high IOFC depending on the ingredient costs. Table 1 also highlights that ingredients are not readily available across all sites and that the cost may vary considerably by site. Thus developing a standard ration may be very site specific. A simple least cost ration formulator (ACIAR LCR) has been developed in the ACIAR project LPS/2013/021 Profitable feeding strategies for smallholder cattle in Indonesia and there is also an associated App (Beefupp) which is also available (K.J. Harper pers. comm.). These have been used to devise rations which promote high live weight gain and IOFC. Table 2 shows least cost rations and cost $/ \mathrm{kg} \mathrm{DM}$ as formulated by the ACIAR LCR for some of the above regions. This shows that the ration formulated for a region based on specific regional costs can vary but still deliver the ME, CP and NDF levels required. By far the lowest cost ration is if a farmer can grow their own cassava and simply chip, dry and store to feed to their cattle. Similar considerations would apply to any home grown feed ingredient eg leucaena, gliricidia, sesbania, indigofera, rice bran etc.

Table 2. Rations formulated by the ACIAR LCR for three regions and potential ration formulation if farmer was to grow own cassava and feed directly to cattle.

\begin{tabular}{|c|c|c|c|c|c|}
\hline Region & Ration \% & $\begin{array}{c}\mathrm{ME} \mathrm{MJ} / \mathrm{kg} \\
\mathrm{DM}\end{array}$ & $\begin{array}{c}\mathrm{CP} \\
\% \mathrm{DM}\end{array}$ & $\begin{array}{l}\mathrm{NDF} \\
\% \mathrm{DM}\end{array}$ & $\begin{array}{c}\text { Cost IDR/kg } \\
\text { DM* }^{*}\end{array}$ \\
\hline $\begin{array}{l}\text { Sumbawa only Gaplek } \\
\text { available }\end{array}$ & $\begin{array}{l}\text { Leucaena } 50 \%, \text { Elephant } \\
\text { grass } 5 \% \text {, Gaplek } 8 \% \text {, rice } \\
\text { bran } 9.7 \%, \text { PKC } 25 \% * *\end{array}$ & 11.0 & 18.0 & 47.6 & 2226 \\
\hline $\begin{array}{l}\text { Sumbawa with home } \\
\text { grown cassava tuber }\end{array}$ & $\begin{array}{l}\text { Leucaena } 35 \% \text {, cassava } \\
\text { tuber } 40 \% \text {, PKC } 25 \%\end{array}$ & 11.6 & 13.4 & 35.7 & 1621 \\
\hline Sumbawa only leucaena & Leucaena $100 \%$ & 11 & 23.3 & 41 & 1667 \\
\hline Central Sulawesi & $\begin{array}{l}\text { Gliricidia } 50 \% \text {, rice bran } \\
32.7 \% \text {, Corn grain } 9.5 \% \text {, } \\
\text { PKC } 7.8 \%\end{array}$ & 11.0 & 18.0 & 38.6 & 2424 \\
\hline $\begin{array}{l}\text { East Java only Gaplek } \\
\text { available }\end{array}$ & $\begin{array}{l}\text { Gliricidia 50\%, Elephant } \\
\text { grass } 18.5 \% \text {, Gaplek } 6.5 \% \text {, } \\
\text { PKC } 25 \%\end{array}$ & 11.0 & 17.4 & 48.5 & 2111 \\
\hline $\begin{array}{l}\text { East Java no tree legumes } \\
\text { available }\end{array}$ & $\begin{array}{l}\text { Elephant grass } 29.8 \% \text {, } \\
\text { Gaplek } 40 \% \text {, PKC } 25 \% \\
\text { Copra meal } 4.2 \% \text {, urea } 1 \%\end{array}$ & 11.0 & 12.0 & 43.3 & 1792 \\
\hline $\begin{array}{l}\text { East Java with home } \\
\text { grown cassava tuber }\end{array}$ & $\begin{array}{l}\text { Gliricidia } 50 \% \text {, Elephant } \\
\text { grass } 10 \% \text {, cassava tuber } \\
40 \%\end{array}$ & 11.4 & 13.2 & 35.1 & 1609 \\
\hline $\begin{array}{l}\text { East Java no tree legumes } \\
\text { available with home } \\
\text { grown cassava tuber }\end{array}$ & $\begin{array}{l}\text { Elephant grass } 25.1 \%, \mathrm{PKC} \\
25 \% \text {, cassava tuber } 40 \%, \\
\text { copra meal } 9.1 \% \text {. urea } 0.8 \%\end{array}$ & 11.0 & 12.0 & 44.3 & 1826 \\
\hline
\end{tabular}


Table 3. Live weight gain, DM intake, estimated ME intake, cost of ration and Income Over Feed Costs of three feeding systems (data from Cowley et al 2020 based on 2013 prices).

\begin{tabular}{|c|c|c|c|}
\hline & $\begin{array}{c}\text { Elephant grass (EG) } \\
(100 \%)\end{array}$ & $\begin{array}{c}\text { Simplified feedlot } \\
\text { (EG 20\%, Onggok 40\%, } \\
\text { Copra meal 20\%, PKC* } 20 \%)\end{array}$ & $\begin{array}{c}\text { High Onggok } \\
\text { (EG20\%, Onggok 70\%, } \\
\text { Copra meal 5\%, PKC 5\%) }\end{array}$ \\
\hline Live weight gain $(\mathrm{kg} / \mathrm{d})$ & 0.23 & 1.0 & 0.23 \\
\hline DM intake $(\mathrm{g} / \mathrm{kg} \mathrm{W} / \mathrm{d})$ & 16.7 & 21.8 & 17.1 \\
\hline $\begin{array}{l}\text { Estimated ME intake } \\
(\mathrm{MJ} \mathrm{ME} / \mathrm{kg} \mathrm{W} / \mathrm{d})\end{array}$ & 0.13 & 0.24 & 0.18 \\
\hline $\begin{array}{l}\text { Cost of ration (IDR/kg } \\
\text { DM) (includes } \\
\text { opportunity labour cost } \\
\text { for forage harvest) }\end{array}$ & 2232 & 1322 & 1737 \\
\hline $\begin{array}{l}\text { Income over feed cost } \\
\text { (IDR/day) (includes } \\
\text { opportunity labour cost } \\
\text { for forage harvest) }\end{array}$ & -2830 & 25758 & -852 \\
\hline $\begin{array}{l}\text { Income over feed cost } \\
\text { (IDR/day) (does not } \\
\text { include labour costs for } \\
\text { forage harvest) }\end{array}$ & 8156 & 27673 & 2603 \\
\hline $\begin{array}{l}\text { Feed conversion ratio } \\
\text { (kg feed DM/kg live } \\
\text { weight gain) }\end{array}$ & 22.2 & 7.4 & 22.3 \\
\hline
\end{tabular}

It follows that a feed with a low FCR (low $\mathrm{kg}$ feed/kg live weight gain) is more likely to have a high IOFC and be more profitable and attractive to a farmer although the daily feed cost might be much higher than a traditional system. An individual farmer may feed for a lower daily feed cost by feeding cheap ingredients eg large amounts of rice straw but it usually results in a lower daily IOFC. The farmer and extension personnel need to understand the difference between lower daily feeding cost (eg rice straw) and daily profit (IOFC) eg by the use of tree legumes or a formulated ration. Of course a higher daily feed cost if it leads to a higher IOFC is the better option but access to credit and risk are just as important in the decision process. Tables 3 and 4 outline examples of this. This also demonstrates that formulating a diet for a high ME content does not guarantee a high IOFC if the animals do not achieve a high DM intake for some reason (compare high onggok ration with simplified feedlot ration where the ME content is similar but for various reasons the intake of the high onggok ration was low).

\section{How to formulate rations}

Rations are often formulated based on some experimental combination of ingredients whereby there is some confidence that a high live weight gain will result. This is usually based on formulating for a high $\mathrm{ME}(>11 \mathrm{MJ} \mathrm{ME} / \mathrm{kg} \mathrm{DM})$ and $\mathrm{CP}$ $(>12 \% \mathrm{CP})$ content. This approach is good but the problem is what to do when one of the ingredients changes markedly in price or becomes unavailable. Similarly a new ingredient might emerge at a very low price (eg cassava tuber tips during the peeling process for factories) and so how does one use this opportunity to formulate a new ration. For example, cassava tuber tips are often available locally, intermittently, at a very low cost compared to gaplek or onggok and could be used to feed cattle. The problem is how to use them. The best approach is to have some ration formulation system (eg ACIAR LCR) that formulates a ration within certain nutritional constraints eg levels of ME, CP and neutral detergent fibre (NDF) and mineral levels. This is the standard approach used by large commercial feedlots or feed companies to formulate 
rations for specific nutrient content (usually a range or minimum value). There are many commercial LCR systems but they are too expensive for individual farmer advice, cooperatives or smaller commercial feed companies.

The ACIAR LCR and the Beefupp App have been developed for local use and extension agencies. These have been used to devise rations which promote high live weight gain and IOFC. The ACIAR LCR does not predict an IOFC but it does formulate a ration which will have certain nutritional characteristics (levels of ME, CP and NDF) which from feeding standards and experiments are known to result in a high live weight gain and low FCR. These are characteristics which usually lead to better IOFC but not necessarily so and so the full evaluation needs to be done from formulation of a ration with ACIAR LCR, measurement or prediction of live weight gain from feeding standards or local experiments and then calculation of IOFC so as to evaluate the most profitable strategy. Table 3 also shows the limitations of applying the ACIAR LCR without consideration of some other factors. Rations can be formulated for least cost based on a requirement for a range of $\mathrm{ME}, \mathrm{CP}$ and $\mathrm{NDF}$ but there may be features of ingredient use which limit their percentage in a ration eg it has been found that gaplek inclusion should not exceed $40-50 \%$ in a ration and palm kernel cake and copra meal inclusion should not exceed $25 \%$ of each ingredient. Also high levels of bran products (rice bran and wheat pollard) have very low Ca compared to $\mathrm{P}$ and this needs to be balanced.

The ACIAR LCR system enables a range of formulations to be devised and compared as to cost of formulated ration and, with these restrictions in ingredient use, some confidence can be placed in the live weight gain which will result. This will depend on the safe inclusion limits of ingredients and the level of feeding of the formulated ration. Formulated rations should be fed at a high level preferable ad lib, or supplemented to a cut and carry forage at a high level if good responses are to be obtained.

Table 4. Live weight gain and Feed conversion efficiency of EuroX bulls fed in a village based system and supplemented with different supplements formulated by the ACIAR LCR system (Setiadi et al 2020)

\begin{tabular}{|c|c|c|c|c|c|}
\hline & $\begin{array}{c}\text { Current } \\
\text { feeding } \\
\text { system } \\
(\mathrm{CFS})+ \\
1 \mathrm{~kg} \text { wheat } \\
\text { pollard/day }\end{array}$ & $\begin{array}{l}\text { CFS }+2 \% \mathrm{~W} / \mathrm{d} \\
\text { supplement of } \\
50 \% \text { gaplek, } \\
25 \% \text { PKC, } 25 \% \\
\text { copra meal }\end{array}$ & $\begin{array}{l}\text { CFS }+2 \% \mathrm{~W} / \mathrm{d} \\
\text { supplement of } \\
\text { local } \\
\text { concentrate } \\
\text { from feed } \\
\text { company } \\
\end{array}$ & $\begin{array}{c}\text { CFS }+2 \% \text { W/d } \\
\text { supplement of } 30 \% \\
\text { gaplek, } 20 \% \text { copra } \\
\text { meal, } 20 \% \text { PKC, } \\
20 \% \text { corn cob, } 10 \% \\
\text { rice bran } \\
\end{array}$ & $\begin{array}{c}\mathrm{CFS}+2 \% \mathrm{~W} / \mathrm{d} \\
\text { supplement of } \\
20 \% \text { copra meal, } \\
20 \% \text { PKC, } 40 \% \\
\text { corn cob, } 20 \% \\
\text { rice bran } \\
\end{array}$ \\
\hline $\begin{array}{l}\text { Live weight } \\
\text { gain (kg/day) }\end{array}$ & 0.84 & 1.08 & 0.87 & 0.85 & 0.78 \\
\hline $\begin{array}{l}\text { Feed } \\
\text { conversion } \\
\text { efficiency }(\mathrm{kg} \\
\text { DM intake/kg } \\
\text { live weight } \\
\text { gain) }\end{array}$ & 13.4 & 8.3 & 12.1 & 8.0 & 12.8 \\
\hline
\end{tabular}

Table 5 gives an example of various inclusion levels of gaplek and Table 6 gives results for the level of supplement fed. The data of Marsetyo et al (2020) in Table 6 clearly show that the level of supplement should be high if live weight gain and IOFC are to be increased to high levels.

\section{Feed ingredients}

The range of feed ingredients is very large but when examined on a national and regional basis for volume the list is much smaller. Restricted supply chains, such as under Covid-19, inhibit the transfer of byproducts around Indonesia so more 
emphasis needs to be placed on using local resources or growing feedstuffs locally. Commercial feedlot rations rely on the use of grain or high energy by-products.
Internationally, cereal grains, maize silage, by-products such as soybean hulls, potato waste, biofuel waste (distillers grains) are popular.

Table 5. Live weight gain, DM intake, feed conversion efficiency, feed cost of gain in EuroX bulls of rations varying in gaplek and protein meal content (data from Retnaningrum et al 2020 based on 2019 prices).

\begin{tabular}{|c|c|c|c|c|c|}
\hline & $\begin{array}{c}30 \mathrm{C} \\
30 \% \text { gaplek* } \\
25 \% \text { PKC, } 25 \% \\
\text { copra meal, } \\
20 \% \text { maize } \\
\text { stover }\end{array}$ & $\begin{array}{c}40 \mathrm{C} \\
40 \% \text { gaplek, } \\
20 \% \text { PKC, } 20 \% \\
\text { copra meal, } \\
20 \% \text { maize } \\
\text { stover }\end{array}$ & $\begin{array}{c}50 \mathrm{C} \\
50 \% \text { gaplek, } \\
15 \% \text { PKC, } 15 \% \\
\text { copra meal, } \\
20 \% \text { maize } \\
\text { stover }\end{array}$ & $\begin{array}{c}60 \mathrm{C} \\
60 \% \text { gaplek, } 10 \% \\
\text { PKC, } 10 \% \text { corra } \\
\text { meal, } 20 \% \text { maize } \\
\text { stover }\end{array}$ & $\begin{array}{c}70 \mathrm{C} \\
70 \% \text { gaplek, } \\
5 \% \text { PKC, } 5 \% \\
\text { copra meal, } \\
20 \% \text { maize } \\
\text { stover }\end{array}$ \\
\hline $\begin{array}{l}\text { Live weight } \\
\text { gain }(\mathrm{kg} / \mathrm{d})\end{array}$ & 1.27 & 1.35 & 1.05 & 0.76 & 0.30 \\
\hline $\begin{array}{l}\text { DM intake } \\
(\% \mathrm{~W} / \text { day })\end{array}$ & 2.1 & 2.2 & 2.1 & 2.0 & 1.6 \\
\hline $\begin{array}{l}\text { Feed } \\
\text { conversion } \\
\text { efficiency }(\mathrm{kg} \\
\text { DM intake } / \mathrm{kg} \\
\text { live weight } \\
\text { gain) }\end{array}$ & 5.44 & 5.56 & 6.80 & 8.46 & 19.32 \\
\hline $\begin{array}{l}\text { Feed cost of } \\
\text { gain (IDR/kg } \\
\text { live weight } \\
\text { gain) }\end{array}$ & 18,016 & 18,554 & 24,025 & 30,894 & 71,315 \\
\hline
\end{tabular}

Table 6. Live weight gain, DM intake, feed conversion efficiency and daily Income over feed cost of Ongole bulls fed corn stover basal diet supplemented with a 50:50 DM ratio of gaplek and gliricidia (CG)at levels of $0.4,0.8,1.2$ and 1.6\%W/day (data from Marsetyo et al 2020 based on 2019 prices)

\begin{tabular}{lccccc}
\hline & Corn stover (CS) & CS + 0.4CG & CS + 0.8CG & CS + 1.2CG & CS + 1.6CG \\
\hline $\begin{array}{l}\text { Live weight gain } \\
\text { (kg/d) }\end{array}$ & 0.31 & 0.42 & 0.51 & 0.60 & 0.69 \\
$\begin{array}{l}\text { Total DM intake } \\
\text { (\%W/day) }\end{array}$ & 2.35 & 2.69 & 2.89 & 3.08 & 3.28 \\
$\begin{array}{l}\text { Feed conversion } \\
\text { efficiency (kg DM } \\
\text { intake/kg live weight } \\
\text { gain) }\end{array}$ & 18.4 & 16.0 & 13.6 & 13.0 & 12.6 \\
$\begin{array}{l}\text { Income over feed cost } \\
\text { (IDR/bull.day) }\end{array}$ & 8,413 & 10,607 & 13,225 & 14,623 & 15,606 \\
\hline
\end{tabular}

Whilst there is a large amount of corn grown in Indonesia it is hard to justify an expansion to feed cattle when more efficient poultry feeding systems are available. Local supply chains, eg NTB and NTT, could utilise cheap local grain effectively for cattle as an ingredient in formulated rations but in general, cereal grain is best fed to monogastrics. Ruminants are better placed to use forages and crop by-products. Tree legume systems have been developed which are very profitable and result in high live weight gain especially in regions where supply of other feed ingredients locally are difficult eg the drier regions of eastern islands of Indonesia. The range of feed ingredients which have a high ME is low. These might include cassava and its various 
by-products, wheat bran/pollard from the local processing of imported wheat, soybean hulls from imported or locally grown soybean, soybean tofu by-product, palm kernel cake and copra meal. These have variable availability across Indonesia and variable price so a ration developed for East Java may not have the ingredients or only available at a high price in Central Sulawesi. The advantages of formulating rations by some LCR is obvious in these circumstances.

Of all the ingredients with high ME which can be grown locally, especially in the relatively land rich areas of Sulawesi, NTB and NTT, cassava offers the most promise. Cassava has expanded rapidly across Asia to meet biofuel demand and demand for local cassava products for human consumption. It is an easy crop to grow with much local expertise in farmers and its price has declined for international trading recently. This has led to a reduction in area grown. However it could be used to value add by feeding to cattle. Gaplek and onggok are common products although the availability of onggok has declined recently in the regions. Gaplek has a much higher starch content and is suitable for feeding to cattle. Cassava peels and cassava leaf are also available locally near factories. However, if cassava is grown for cattle feed then it could be grown and processed in a much simpler process than the traditional process of peeling and grinding for processing in a factory. Whole cassava tubers could be grown by individual farmers, chopped dried and ground and used in a formulated ration for their own cattle. This process would reduce the HCN levels to safe levels. Ensilage would also be another means of processing for storage and to reduce $\mathrm{HCN}$.

Searching for forages (tree legumes, grasses and forage legumes) which can be used locally and the use of high ME crops such as cassava, grown locally for cattle rather than for a factory, would develop local supply chains for cattle resulting in lower FCR and higher IOFC. Table 2 outlines the feed cost of some formulated rations in various regions based on local ingredients or imported from another region. The examples from Sumbawa and East Java, using locally grown cassava or tree legume, highlights this and the potential cost structure that could be devised. This also shows that the $100 \%$ leucaena based systems in NTB are a comparable low cost ration but if leucaena is in limited supply other rations can be devised with comparable nutrient composition and cost. This is the advantage of using a LCR system. Leucaena based systems have resulted in the most profitable systems in the NTB region (Dahlanuddin et al 2019).

Cassava is intensively grown in various regions of Indonesia at present, eg Sumatra and East Java, where large cattle populations could just use this if formulated correctly. The whole cassava tuber could be processed for cattle. Cassava leaf and cassava peels could also be used as products from the farming system. The question for a local supply chain in these traditional cassava growing areas is whether to direct the product to a factory for processing or whether to use it in cattle. The optimum will depend on price but the current decline in cassava price opens the potential to value add through cattle rather than to move out of cassava production. In the more marginal areas of Indonesia there would seem to be potential to develop systems based on feeding whole cassava tuber combined with cassava leaf and tree legume for $\mathrm{CP}$, formulated within an ACIAR LCR system, to develop rations with low FCR, high live weight gain and higher IOFC than current systems. The mindset needs to change where beef cattle could value add onto an existing crop using local supply chains both within a farm or across farms within a region to supply ingredients. Table 5 shows results of using gaplek for a variety of combinations of ingredients with Limousin $x$ Ongole cattle in East Java. These results showed the very high live weight gain that could be achieved equal to the best in commercial feedlot rations anywhere in the world but they also showed the wide difference in 
IOFC for rations designed to have similar ME values. This demonstrates both the strength and the weakness of an ACIAR LCR approach to formulate rations based on local supply chains. It demonstrated that ACIAR LCR is useful but that limits for ingredient inclusion need to be defined otherwise results can be disastrous. In these studies and in others (Ba et al 2008, Cowley et al 2020) gaplek and onggok have a maximum inclusion level of $40-50 \%$ beyond which intake declines with the result that live weight gain declines and IOFC decreases markedly. Similar anecdotal results are obtained for inclusion of palm kernel cake and copra meal in rations which are both recommended to have upper levels of inclusion of $25 \%$ for palatability reasons. These nutritional limits do not have any known basis in nutritional principles but practically these limits are widely recognised. These limits can be easily incorporated into the ACIAR LCR input to formulate a ration but it is important to know these limits and demonstrate them experimentally. It is practically very important to know this when devising local supply chains to supply ingredients for cattle fattening systems.

These considerations outline another major factor in using ingredients and an ACIAR LCR system. Any LCR system primarily formulates on least cost to supply a ration with a defined ME range. The first principle is to have a ME range high enough to promote a high live weight gain. This is usually a $\mathrm{ME}$ value around $12 \mathrm{MJ} \mathrm{ME} / \mathrm{kg}$ $\mathrm{DM}$ but we have defined a minimum in the ACIAR LCR of 11MJME/kg DM (it can be set at any level by the operator) so as to access more local feeds with a compromise on a potentially lower live weight gain. This value can be changed but was used for the simulations used here. From nutritional principles, rations with the same ME content should result in the same live weight gain. However this may not be so. One reason is that ingredients are usually not analysed for ME content and users rely on book values and so variation in ME content between reference sources leads to variation in the ME content of the formulated ration. Large commercial companies do have systems for analysing chemical composition and so they have a more effective quality assurance program than smaller companies or cooperatives or individual farmers who rely more on book values from some feed library. These book values can vary markedly between sources.

A second reason is that rations with the same ME content may perform differently because intake is different. For example animals will consume more of a sorghum grain based ration than a barley grain based ration to give the same live weight gain. The cost $/ \mathrm{kg}$ ration might be lower for the sorghum based ration than the barley based ration but the FCR is higher requiring more feed for gain and hence the IOFC may not be as good. In a similar fashion if the ingredient mix leads to low intake, eg when gaplek is $>50 \%$ inclusion, then the FCR is very high and the IOFC very low (see Table 3). Simply formulating without some consideration of the intake response and levels of inclusion can lead to disastrous results. Nevertheless, through experimentation and experience these levels can be defined and the ACIAR LCR system would give a better outcome than an ad hoc approach.

The $\mathrm{CP}$ requirement is also very important and Indonesian breed types of Ongole and Bali cattle are different to breeds upon which the international feeding standards are based. A series of experiments defined minimum $\mathrm{CP}$ requirements for early weaned Bali bulls and Ongole bulls and for more mature fattening Ongole bulls (Antari et al 2014, Quigley et al 2014). They found minimum requirements were approximately $12 \% \mathrm{CP}$ but there was variability between experiments. More mature fattening bulls also required $12 \% \mathrm{CP}$. For these reasons it is suggested when using the ACIAR LCR system for fattening bulls with live weights of around $200 \mathrm{~kg}$ for Bali bulls and 300kg for Euro x Ongole bulls, Ongole bulls or Brahman cross bulls that requirements in the 
formulated ration be set at a minimum of 11 MJME/kg DM, minimum of $12 \% \mathrm{CP}$ and NDF $20-75 \%$ (with enough effective NDF ie long fibres).This should give enough flexibility to meet requirements for high live weight gain and minimal digestive or nutritional problems. However when using the ACIAR LCR the minimum and maximum levels for ME, $\mathrm{CP}, \mathrm{NDF}$ and specific minerals can be set depending on the operator requirements. It is easier to formulate on ME, CP and NDF and then check minerals which can be adjusted to meet requirements and $\mathrm{Ca} / \mathrm{P}$ balance by addition of a mineral mix if required.

\section{Way forward}

The current pandemic has highlighted the need to be flexible in cattle fattening systems and to develop local feed supply chains and local beef cattle supply chains. This has the advantage that farmers can participate in the higher value supply chains but have flexibility in market options. Currently in Indonesia there are a range of forages, tree legumes, by-products and crops which could be utilised. Some crops could be grown just for cattle feed, eg cassava, which is contrary to current practices. Combinations of cassava whole tuber and tree legumes offer a solution to local supply chain issues and provide a means of formulating rations to promote high live weight gain at competitive costs. However some expertise is required in advisory services to formulate these rations. Large commercial feed companies can provide a QA product with the confidence that it will deliver a high live weight gain. This comes at a higher cost but may be a safer option. Smaller feed companies, co-operatives (as in the dairy industry) and farmer groups could use the LCR principle. The beef industry would benefit by developing feed co-operatives and smaller feed supply companies that can supply a QA product at a competitive price enabling IOFC to be much higher for the farmer. We have developed a simple ACIAR LCR system to enable them to make changes to a ration formulation to take advantage of fluctuating ingredient costs and still deliver a high quality product. This enables these groups to participate in the supply chain and for individual farmers to be able to participate in the supply chain of higher quality beef and volume helping Indonesia to meet the twin goals of farmers making more money and greater self-sufficiency nationally in the supply of beef to the market.

\section{ACKNOWLEDGMENT}

The authors thank the Australian Centre for International Agricultural Research (ACIAR) for funding the bulk of this work and members of the ACIAR project LPS/2013/021 "Profitable feeding strategies for smallholder cattle in Indonesia" for access to data presented here

\section{REFERENCES}

Antari, R., Syahnair, T. M., Mayberry, D. E., Pamungkas, D., Marsetyo, Quigley, S. P., \& Poppi, D. P. (2014). Crude protein requirements for growth of Ongole (Bos indicus) and Bali (Bos javanicus) bulls. Joint International Symposium on the Nutrition of Herbivores/International Symposium on Ruminant Physiology, 30.

Aryogi, Sumadi, H. W. (2005). The performance of Ongole grade cross cattle in low land area (A case study at kota Anyar sub district, Probolinggo district, East Java). Prosiding Seminar Nasional Teknologi Peternakan Dan Veteriner, 104-109.

Ba, N. X., Van, N. H., Ngoan, L. D., Leddin, C. M., \& Doyle, P. T. (2008). Amount of cassava powder fed as a supplement affects feed intake and live weight gain in laisind cattle in Vietnam. Asian-Australasian Journal of Animal Sciences, 21(8), 1143-1150. https:// doi.org/10.5713/ajas.2008.70479

Cowley, F. C., Syahniar, T. M., Ratnawati, D., Mayberry, D. E., Marsetyo, Pamungkas, D., \& Poppi, D. P. (2020). Greater farmer investment in well-formulated diets can increase liveweight gain and smallholder gross 
margins from cattle fattening. Livestock Science, 242, 104297. https: //doi.org/10.1016/j.livsci.2020.104297

Dahlanuddin, Panjaitan, T., Waldron, S., Halliday, M. J., Ash, A., Morris, S. T., \& Shelton, H. M. (2019). Adoption of leucaena-based feeding systems in Sumbawa, eastern Indonesia and its impact on cattle productivity and farm profitability. Tropical GrasslandsForrajes Tropicales, 7(4), 428-436. https: //doi.org/10.17138/TGFT(7)428-436

Marsetyo, Sulendre, I. W., Takdir, M., Harper, K. J., \& Poppi, D. P. (2021). Formulating diets based on whole cassava tuber (Manihot esculenta) and gliricidia (Gliricidia sepium) increased feed intake, liveweight gain and income over feed cost of Ongole and Bali bulls fed low quality forage in Central Sulawesi, Indonesia. Animal Production Science. https:// doi.org/10.1071/AN20297

Pamungkas D, Antari R, Mayberry DE, P. D. (2012). A growth comparison of Ongole and European cross cattle kept by smallholder farmers in Indonesia. Proceedings of the 15th AAAP Animal Science Congress, Thailand, 1-4.

Priyanti A, Mahendri IGAP, Cahyadi F, C. R. (2012). Income over feed cost for small- to medium-scale beef cattle fattening operations in East Java. $J$. Indonesian Trop. Anim. Agric, 37, 195-201.

Quigley, S. P., Dahlanuddin, Marsetyo, Pamungkas, D., Priyanti, A., Saili, T., McLennan, S. R., \& Poppi, D. P. (2014). Metabolisable energy requirements for maintenance and gain of liveweight of Bali cattle (Bos javanicus). Animal Production Science, 54(9), 1311. https://doi.org/10.1071/AN14355

Ratnawati D, Cowley F, Mayberry D, Pamungkas D, P. D. (2015). Concentrate supplementation for crossbred bulls to increase profitability of smallholder fattening operations in East Java, Indonesia. Jurnal Ilmu Ternak Dan Veteriner, 20(1), 42-48. https://doi.org/10.143 34/jitv.v20i1.1115

Retnaningrum, S., Kusmartono, Mashudi, Harper, K. J., \& Poppi, D. P. (2021). Formulating rations with cassava meal to promote high live weight gain in crossbred Limousin bulls. Animal, 15(2), 100125. https://doi.org/10.10 16/j.animal.2020.100125

Wirdahayati, R. B. (1994). Reproductive characteristics and productivity of Bali and Ongole cattle in Nusa Tengarra Indonesia. University of Queensland, Australia. 